\title{
Children of parents in prison
}

\author{
Dora Black
}

Every year in England and Wales 100000 children lose their fathers to prison ${ }^{1}$ and an unknown number, in excess of $\mathbf{3 0 0 0}$ suffer their mother's imprisonment. ${ }^{2}$ In many cases the parent was a single parent, and in some cases both parents are convicted and imprisoned for the same offence simultaneously. This paper examines the fate of these 'orphans of justice', ${ }^{3}$ looks at the provision for children to accompany their mothers to prison and whether it meets the children's needs, considers the role of health care and other professionals in the care of these children, and makes recommendations for improvements in the provision of services for families caught up in the criminal justice system.

\section{Children of criminal fathers}

Findings from several studies indicate that having a father who has committed a crime is a risk factor for delinquency in boys. ${ }^{4}$ This risk is compounded by the absence of father from home for long periods during childhood. Studies of the impact on families of the loss of father to prison help us to understand why these children are at such high risk. A study by Shaw of 415 men received into a prison with a sentence of six months or less found that about half (194) were married or cohabiting and had responsibility for more than 378 children. The same sample had a further 196 children with whom they were no longer living because of divorce, separation, or desertion. ${ }^{3}$ Four of the men were single parents. On the basis of these findings, Shaw estimated that in 1984, the year of the study, approximately 75000 males over 21 years of age were received into prison who would have between them about 100000 children. There would in addition be children of younger men. Thus, more than half a million children under 16 years have experienced the imprisonment of their father on one or more occasions-that is, $5 \%$ of all children in England and Wales.

These children are among the most deprived in our society and their father's imprisonment compounds their deprivation as their mothers struggle to cope with debt, poverty, loneliness, ostracism, stigma, and homelessness. In addition, they encounter difficulties that other single parents do not. They may not know where their husband is; they may arrive at a distant prison for a visit, encumbered by children and their paraphernalia, after a long journey by inadequate transport only to find he has been moved without notification. Visiting areas are often unsuitable for children, drab and uninviting, with few toys, little space, and no privacy for intimate discussion. The women feel they have to put on a brave face and cannot tell the fathers their problems. The men often ask for supplies that can be ill afforded but cannot be denied them without their women revealing their destitution. One study found that on average each man in prison is supported by his family to the tune of over $£ 500$ per annum, which has to come from the meagre provision made by the state for prisoners' families, thus impoverishing them further.

For many of the mothers, a father's imprisonment means the loss of their only source of income and financial knowledge and skill. The mothers are fearful of asking for state help in case their children are removed from them and they are often ignorant of their right to benefits. ${ }^{6}$ There is no statutory provision for them to receive such information, and the probation service is seen as giving help to offenders rather than their families. ${ }^{7}$ They tend to borrow from family, friends, and from loan companies with high rates of interest, impoverishing the family further.

Often other agencies, schools, health visitors, and social services are unaware of the incarceration of the father, ${ }^{78}$ and two thirds of mothers conceal the fact even from the children and their own families, using such evasions as 'working away' or 'in hospital'. The children therefore often learn of their father's imprisonment from other children or, not knowing, feel abandoned by him and fear that their mother may do the same. ${ }^{1}$

It is difficult for children to have access to their fathers frequently enough to maintain a relationship, and this leads to problems on release. There are other problems related to the fact that prison in many ways infantilises the men, while the women outside have matured through having to manage children and finances alone. Many of the women fear their man's release because they do not wish to revert to the previous dependent state. The lack of adequate prerelease home visits and difficulties in communication mean that adequate preparation has not been made to deal with these difficulties. ${ }^{5}$

For some children and families the imprisonment of father may be a relief if it removes an abusive, violent, or spendthrift man. These children and their mothers may resist attempts by father to have them visit him, and it is unclear whether the new provisions of the Children Act 1989 concerning continuing parental responsibility will affect the children's right to refuse to visit. Children whose father kills their mother may have witnessed the killing, and of those who do a high proportion 
develop a psychiatric disorder, notably posttraumatic stress disorder and conduct disorder. ${ }^{9}$ Many of these children fear their father and hate him for depriving them of their mother. As they are effectively parentless they suffer more trauma as attempts are made to find them a home, and the families of the mother and father battle over their custody or give inadequate care because of their own grief and anger. These children more than those whose mother is caring for them suffer from changes of carer, home, school, and friends. Their burdens may be increased if they live with paternal relatives who see it as their duty to maintain the children's contact with the feared and hated father.

The children of a man who was already separated from their mother before his arrest may have limited or no access to him after imprisonment, even though they enjoyed contact with him before, as there may be no one willing to take on the job of accompanying them to prison. It is the right of the child to be accorded contact with the father but, in practice, this right like many others may be denied them.

The children too find themselves stigmatised at school by their father's crime. Surprisingly little research is available on the psychiatric disorders or school problems of prisoner's children. Richards has suggested that the effects on children of their parents' imprisonment is similar to those of divorce but that, in addition, imprisonment may lead to divorce so that a child may suffer from both kinds of upheavals. ${ }^{10}$ He draws attention to the high incidence of behavioural and other psychiatric problems in children of divorce and concludes that children of prisoners will be at high risk of similar problems.

Children of imprisoned fathers therefore suffer all the disadvantages of children of single parents (poverty, homelessness, maternal depression) with the added difficulties of shame, stigma, inadequate information, and loss of contact with the father. They may have to cope with their anger and fear of a father jailed for killing their mother or sibling, or who physically or sexually abused them, who nevertheless has the power to compel their attendance at a prison which may require, in addition, that they undertake a harrowing journey.

Their role model for male behaviour on the

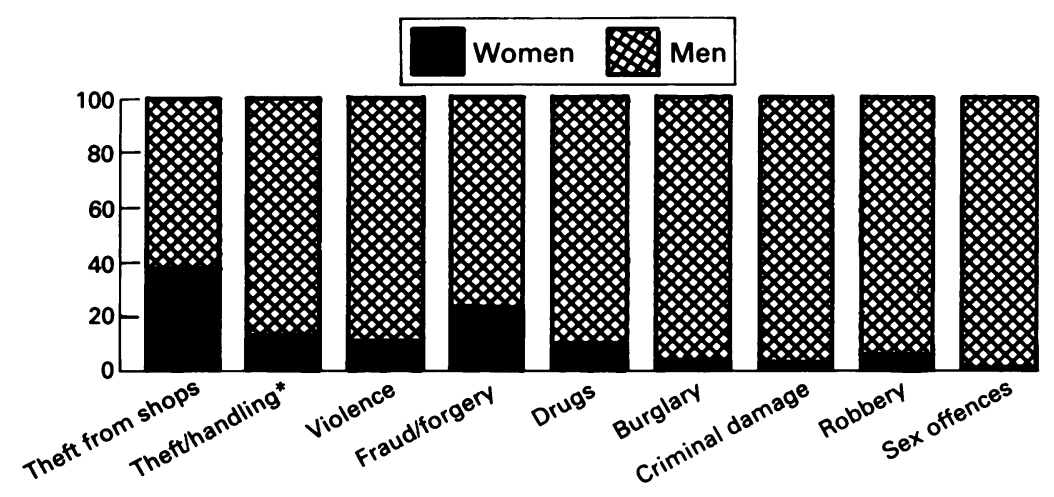

Percentages by sex of persons found guilty or cautioned for indictable offences in $1989 .{ }^{16}$ ${ }^{*}$ Excludes theft from shops. other hand may be that of a glamorous hero whose exploits bring pride and status to the family. This may be particularly so in the case of terrorist activity. ${ }^{11}$ In either case the evidence is that having a criminal father enhances the likelihood of male delinquency and female social difficulties. ${ }^{410}$

\section{Children of criminal mothers}

Most children whose fathers go to prison remain with their mothers. When mothers are imprisoned, fathers rarely care for them and they face much more disruption in their care, place of residence, and school. ${ }^{1213}$ The problem is much smaller numerically, although exact numbers are difficult to ascertain as some women who are imprisoned refuse to reveal the fact that they have dependent children, fearing that the children will be taken into care and will not be restored to them on their release from prison. Woodrow has calculated that at least 3000 children a year are affected by their mother entering prison. ${ }^{2}$ In addition, about 70 babies a year are born to women serving prison sentences-usually accommodated in NHS hospitals with an accompanying prison officer for the birth. One third of the women had children under 4 years of age.

A small proportion of imprisoned women will be allowed to have their infants with them in prison. There are three women's prisons in England and Wales (none in Scotland or Northern Ireland) which accept a total of 36 babies in all: at Holloway (London) and Styal (Cheshire) they can stay until 9 months of age, and in Askham Grange (an open prison in Yorkshire) until 18 months.

Far fewer women than men offend and their offences are overwhelmingly non-violent. About half a million offenders were found guilty or cautioned for indictable offences in 1989. Of these, approximately $83 \%$ were men and $16 \%$ women. ${ }^{14}$ The figure shows that compared with men, women's offences are overwhelmingly non-violent. Half of the prison sentences for women were for non-payment of fines; the majority of mothers in prison are remand prisoners, of whom only one third will eventually receive custodial sentences. ${ }^{15}$ Unfortunately there is a trend to use prison increasingly for first offenders, both men and women. ${ }^{16}$

The children remaining outside are cared for in the main by relatives, usually middle aged or elderly and often as financially and socially disadvantaged as the mothers themselves. Some children go into local authority care, and many of those have more than one foster parent during the sentence (L Catan, B Lloyd, unpublished report, 1989). The children may also be separated from siblings and their father, ${ }^{17}$ or older siblings may have to do much of the parenting. When the mothers leave prison they are often in great debt, with rent arrears or no accommodation and unable to find employment. They cannot therefore take back their children and may find themselves forced back into relationships with violent and alcoholic men. ${ }^{13} 18$

In 1986 a census was taken of 11 prison service establishments for women in England 
and Wales. This showed that 340 women prisoners had 455 children under 5 years of age, $4 \%$ of the children were in mother and baby units with their mother, $69 \%$ were with relatives, $7 \%$ were with friends, $19 \%$ were in care, and $1 \%$ had details unknown. ${ }^{19}$

Those few children who accompany their mothers into prison have problems brought about by their own incarceration. Catan was commissioned by the Home Office to study the development of babies in prison. ${ }^{20}$ Using monthly recordings of the Griffiths's scales she found that, compared with those of similar age left behind, there was little difference in overall development (most babies were in prison for a short time-weeks rather than months). The test scores of babies who spent longer than average in the units revealed a gradual developmental decline over a four month period in two areas of development only-locomotor and cognitive. The developmental levels of babies left outside did not change over a four month period from the start of their mothers' sentence, unit babies' scores declined gradually and, by the fourth month, there was a statistically significant difference between the score of the two groups which increased with time spent in the prisons. In a later study, Catan and Lloyd established that the most likely cause of this discrepancy was the lack of stimulating toys and everyday objects, and the reluctance of the mothers to allow the babies to sit and crawl on the floor because of hygiene and interference from other mothers and children (L Catan, B Lloyd, unpublished report, 1989). The children spent long hours strapped in prams, chairs, and bouncers or being carried around.

One of the factors mentioned by the authors of the study was the lack of child centred expertise available to the mothers. Health visitors' visits were sporadic or lacking and the professional expertise of nursing and prison staff lay in directions other than child care and development. As a result of these studies efforts are being made to remedy some of the deficiencies identified. One major advantage of the children being with their mothers is the close bond that they develop. It is therefore distressing to learn that the admission criteria for babies and children, as set out in Circular Instruction $51 / 1983$, are determined by the Home Secretary guided by the prison governors-who depend on considerations other than the primary one of the child's welfare. The availability of places, the length of the mother's sentence, her freedom from mental and physical illness, and her parenting ability have all to be evaluated by them and although they should seek advice from health, probation, and social services they are not compelled to do so.

Parenting ability is very difficult to assess and requires a high level of skill and experience. ${ }^{21} 22$ Similarly the assessment of mental and physical illness and its effect on parenting ability is not a simple matter and requires medical, psychiatric, and psychological knowledge unlikely to be within the compass of a prison governor or even some of his regular advisors.

An assessment of eligibility is made by the governor of the holding prison and conveyed to the governor of the appropriate prison, so the mother is imprisoned initially without her baby while the assessment is made. An overriding criterion is the likely length of the mother's sentence. If the baby will reach 9 or 18 months before the mother finishes her sentence, the baby cannot be admitted. In practice this apparently sensible ruling is not adhered to: babies who may have had an unusually close and intimate relationship with their mother for nine months can be abruptly taken out of the prison to other carers. A governor can and has caused a baby to be removed from prison as a disciplinary measure-with no requirement to consider the needs of the child as paramount. A challenge to that decision was not upheld by the High Court ( $\mathrm{v}$ Secretary of State for the Home Department ex parte Hickling and J H (a minor), 1986).

Imprisoned children have virtually no contact with other members of their family and their separation if it is necessary after nine months can rarely be managed slowly. Separated children cannot be brought to prison frequently enough to mitigate their pangs of grief at the separation. ${ }^{23}$

\section{Needs of children}

Apart from physical nurture, and protection from harm, young children need the contiguity and continuity usually supplied by their parents, in order to develop emotional security as a prerequisite to intellectual and physical development. Because they have so little experience, many events or situations evoke fear and anxiety in a small child and these experiences are modified in the presence of their attachment figures. ${ }^{24-26}$ Disruption of attachment bonds seems to be particularly dangerous between the ages of 6 months and 4 years but it may be damaging earlier. There is evidence that young children who have sudden or repeated separations are more likely to develop psychiatric disorders and are more prone to deviations in personality development, leading to aggressiveness, coldness in personal relationships, difficulties in learning, and a greater tendency to parenting difficulties in adult life. ${ }^{27}$ Children whose attachments are disrupted also have many other disadvantages that are probably cumulative and interactive but it behoves a caring society to try to minimise the number of adversities to which children are subjected.

\section{ARE THESE NEEDS BEING MET?}

Children caught up in the criminal justice system because of their parents' offences are innocent victims. Shaw points out that the question that should be asked is not what harm is done to these children by the imprisonment of their parent, but why this harm is permitted and, in some cases, made to happen. ${ }^{28}$ Prisoners' families suffer from being seen as 'undeserving' or stigmatised as having brought it on themselves. ${ }^{29}$ Shaw asks whether it is just to punish the innocent more than the guilty, or indeed the victims of the offenders. 'The majority of persons received into British prisons under sentence in default of payment and on remand 
remain there for less than three months and many for only a few days or weeks ... . One is forced to ask whether the incarceration of these short sentence prisoners be justified if the children of a significant proportion suffer harm as a result?' As we have seen, most women prisoners fall into this category.

Inspired by a television programme which reported a similar initiative in New York, Holloway prison introduced improvements to the facilities for children visiting their mothers. ${ }^{30}$ Two Sundays a month the children that are separated from their mothers can stay with their mothers for the day in the gym and education block. This is not available for remand prisoners, and while the initiative should be welcomed, it is only likely to be of benefit to older children. For children under 5 years the long gap between visits makes it unlikely that the pangs of grief will be assuaged, and indeed they may be tantalised by the renewed intimacy, only to be sundered again.

\section{RECOMMENDATIONS}

Children need their parents to care for them. Most criminal parents can parent well. Children deprived of their parents rarely find better substitute ones and our society is not meeting the needs of children of offenders. If we are to admit young children to prison with their mothers, we should be providing facilities of the same standard as is mandatory in social service day nurseries. If the children have to be taken from their mothers in prison, the management of the separation must be done gradually, in order to enable the child to attach to a new caretaker before relinquishing the first one. Children's welfare in the prison must be the responsibility of someone of high enough status and sufficient knowledge of children's needs to be able to influence policy and practice. I suggest that this should be a consultant community paediatrician and that the child's welfare, in prison as elsewhere, should be regarded as paramount. All children in prison should have the services of nursery nurses, and a health visitor, and provision should be made for a budget for toys, furnishing, and equipment.

Similarly, community paediatricians working in schools should be aware of prisoners' children and, with the school, monitor their mental health and welfare and that of their family. ${ }^{831}$ Health visitors should be made aware through the probation service of those preschool children whose parents are imprisoned. ${ }^{7}$ Parents in prison should be granted home leave early and should be enabled to keep in touch through provision of telephones and better facilities for children to visit. ${ }^{31}$

No mother or single father should be given a custodial sentence without the judge or magistrate satisfying himself or herself that proper provision has been made for the children. But need so many parents be imprisoned? If a noncustodial alternative is appropriate should we not use it? Other countries have found it possible to use day prisons, bail hostels, and community service and their recidivism rate is no higher than ours. ${ }^{23}$

Legislation may be needed to ensure that children and parents are not wantonly parted. Unless the public needs to be protected (from murderers, some violent offenders, some drug offenders, and some mentally ill offenders), doctors should use their influence as citizens through their parliamentary representative to prevent unnecessary imprisonment of parents.

1 Shaw R. Children of imprisoned fathers. London: Hodder and Stoughton, 1987.

2 Woodrow J. Mothers inside, children outside: what happens to the dependent children of female inmates? In: Shaw $R$, ed. Prisoners' children: what are the issues? London: Routledge, 1992:29-40.

3 Shaw R. Imprisoned fathers and the orphans of justice. In: Shaw R, ed. Prisoners' children: what are the issues? London:

4 West DJ, Farrington DP. Who becomes delinquent? London: Heinemann Educational, 1973.

5 McDermott K, King RD. Prison rule 102: 'stand by your man': the impact of penal policy on the families of prisoners. In: Shaw R, ed. Prisoners' children: what are the issues? London: Routledge, 1992:50-73.

6 Davis A. Men's imprisonment: the financial cost to women and children. In: Shaw R, ed. Prisoners' children: what are the issues? London: Routledge, 1992:74-85.

7 Shaw R. The health visitor and the prisoner's child. Health Visitor 1989;62:248-50.

8 Moore S. A link with normality: the role a school could play to help a prisoner's child in crisis. In: Shaw $R$, ed. Prisoners' children: what are the issues? London: Routledge, 1992:170-9.

9 Black D, Kaplan T. Father kills mother. Issues and problems encountered by a child psychiatric team. Br $\mathcal{F}$ Psychiatry 1988;153:624-30.

10 Richards $M$. The separation of children and parents: some issues and problems. In: Shaw R, ed. Prisoners' children: issues and problems. In: Shaw R, ed. Prisoners' chidd
what are the issues? London: Routledge, 1992:3-12.

11 Hughes WJ. The Northern Ireland troubles: long-term prisoners and their children. In: Shaw R, ed. Prisoners children: what are the issues? London: Routledge, 1992: 147-60.

12 Catan L. Infants with mothers in prison. In: Shaw $R$, ed Prisoners' children: what are the issues? London: Routledge, 1992:13-28.

13 Wilkinson C. The post-release experience of female prisoners In: Morris A, Wilkinson $\mathrm{C}$, eds. Women and the penal system. Cambridge: Institute of Criminology, 1988

14 Home Office. Criminal statistics England and Wales 1989. London: HMSO, 1990.

15 National Association for the Care and Rehabilitation of Offenders. Briefing - women in prison. London: NACRO, 1987.

16 HM Inspectorate of Probation. Report on women offenders and probation service provision. London: Home Office, 1991.

17 Dobash RP, Dobash RE, Gutteridge S. The imprisonment of women. Oxford: Blackwell, 1986.

18 Carlen P. Women's imprisonment: a study in sacial control. London: Routledge and Kegan Paul, 1983. 19 Elton PJ. Mothers and babies in prison. Lancet 1987;ii:501-2. baby units. University of Sussex, 1988. (Occasional paper.) 21 Oates M. Assessing fitness to parent. In: Oxtoby $M$, ed Taking a stand. London: British Agencies for Adoption and Fostering, 1984

22 Black D, Wolkind S, Harris Hendriks J. Child psychiatry and the law. London: Gaskell, 1991.

23 Black D. Imprisoned children. Med Leg f 1988;56:139-49. 24 Bowlby J. Attachment and loss. London: Hogarth Press, 1969.

25 Ainsworth M. Attachment: retrospect and prossect Parkes CM, Stevenson-Hinde I, eds. The place of attachment in human behaviour. London: Tavistock, 1982: 3-30.

26 Bretherton I. Attachment theory: retrospect and prospect. In: Bretherton I, Waters E, eds. Growing points of attachment theory and research. Chicago: University of attachment theory and
Chicago Press, 1985.

27 Rutter M. Maternal deprivation reassessed. Harmondsworth: Penguin, 1981 .

28 Shaw R. Prisoner's children and politics: an aetiology of victimisation. Children and Society 1990;4:315-25.

29 Matthews J. Forgotten victims. In: Light R, ed. Prisoners' families. Bristol: Bristol and Bath Centre for Criminal

30 Marks K. Jailed mothers get days for children. Independent 1991 Jan 14

31 Anderson D, Basson J, Blackstock K, et al. Health, social and educational needs of parents and children affected by imprisonment in Scotland. In: Shaw R, ed. Prisoners children: what are the issues? London: Routledge, 1992 127-46. 